\title{
The Oxford Handbook of Political Theory
}

John Dryzek, Bonnie Honig and Anne Phillips (Eds)

Oxford University Press, Oxford, 2006, 883pp.

Hardcover, ISBN: 0199270031.

Contemporary Political Theory (2008) 7, 232-234. doi:10.1057/cpt.2008.2

The Oxford Handbook of Political Theory is one of a series from the Oxford Handbooks of Political Science, under the general editorship of Robert E. Goodin. The 2006 Political Science Series builds upon the original Goodin-Klingermann New Handbook of Political Science published a decade earlier. The original handbook surveyed the overall discipline of political science with a section on political theory (at that time comprising four key essays by Young, Parekh, von Beyme and Barry). Iris Marion Young's essay from the original handbook recognized Arendt's political theory as a 'milestone' (as did Parekh's), noting the decline in understandings of the political as a participatory and rational activity of citizenship. Young emphasized the continuing politiciziation of the social in a great deal of contemporary political theory; a theme not overly emphasized in the new handbook edition specific to political theory. It is a testament to the continuing relevance of political theory and other aspects of political science that this original handbook could blossom into a 10 plus series of books about the current state of the discipline. As a way of illustrating the manner in which political theory has really come into its own of late, this impressive handbook edited by Dryzek, Honig and Phillips contains 46 entries including the introduction. The series in which it is located 'aspires to shape the discipline, not just report on it' and aims to 'combine critical commentaries on where the field has been together with positive suggestions as to where it ought to be heading' (p. ii).

In the Introduction, the authors point out that in the pursuit of any one ideal, it is important not to lose sight of all the others. The handbook does not seek to promote any one ideal, but rather wants to showcase the pluralism of contemporary political theory, understood by the authors as a key feature and major strength of the field. Beginning with the question, What is Political Theory? the authors define political theory as 'an interdisciplinary endeavor whose centre of gravity lies at the humanities end of the happily still undisciplined discipline of political science' (p. 4). They recognize that the challenge for the identity of political theory has been how to locate its position in terms of its relationship to other disciplines including political science, history and philosophy. 'The way political theory positions itself in relation to political science, history, and philosophy can be read in part as reflections 
on the meaning of the political' (p. 10). Important locations include the relationship of political theory with 'real-world' politics and the institutional landscape, as well as the relationship between canonical political theory and newer developments. The discussion of contemporary themes and developments include liberalism and its critics, liberal egalitarianism, communitarianism, feminism, democratic and critical theory, green political theory and post-structuralism. This is set in the context of political theory and the global turn and current trajectories of political theory and political science. The handbook is organized into the following sections: contemporary currents, the legacy of the past, political theory in the world, state and people, justice, equality and freedom, pluralism, multiculturalism and nationalism, claims in a global context, the body politic and testing the boundaries with a final section on the old and new.

One of the most compelling sections of the handbook is Part X, 'Testing the Boundaries', where political theory engages in dialogue with other disciplines such as cultural studies, the environment, political economy and social theory. The essays are set within the context of two current opposing trends in the academy, the trend of tightening the boundaries of perceived disciplines vs cross-disciplinary and interdisciplinary work, with the essays in the handbook emphasizing the importance of the latter trend (p. 34). While there has been a tendency for the emergence of a third position, where other disciplines attempt to appropriate the unique insights of political theory (a tendency not mentioned yet exemplified by the type of critical sociology practised by Bauman and Beck), Dean's contribution introduces the useful notion of an 'interface' when discussing the relationship between political theory and cultural studies. 'The work at the interface of political theory and cultural studies is not a blending of the strengths and insights of the two fields into something new. Instead, this interface is a contingent, interlinked and changing configuration of thinking from two sites about the contemporary world and the production of the political' (p. 754). Helliwell and Hindess ask how the relationship between political theory and social theory should be thought about and conclude that the most significant differences between the two disciplines is the relationship between normative and descriptive/explanatory issues in political and social life, with many political theorists focussing upon normative issues and many social theorists suggesting the two cannot be separated (p. 821). They suggest political theorists would do well to recognize how much political theory and social theory have in common.

It would seem that given the handbook is about political theory, Helliwell and Hindess would have done better to emphasize the differences between political and social theory rather than their apparent similarities, particularly in the context of Young's overview in the original handbook of the continuing politiciziation of the social and the decline in understandings of the political 
as about public participation. One key difference between political and social theory is that political theory has a public dimension while social theory is neither public nor private. Another important consideration is that historically political theory can be traced back to 3,000 years, yet the discipline of social theory/sociology is a modern phenomenon emerging in the last 300 years or so. Analyses that emphasize the similarities between political and social theory don't seem to see as problematic the appalling contemporary situation where political theory is understood as a sub-branch of social theory. In the Introduction, the editors claim that they support the trend to interdisciplinary work and that there is much to learn from other areas of study (p. 34). If the meaning of interdisciplinary work is respect for the shifting terrains of disciplines with a view to enhancing the study of various areas that is good for all disciplines, but when some disciplines attempt to appropriate other disciplines hierarchically, the real value of 'interdisciplinary synthesis' becomes highly questionable. Overall, the essays in this handbook provide a lucid account of the state of political theory and its position within political science and the disciplines more generally.

Mary Walsh

School of Business \& Government, University of Canberra,

Australia 